\title{
Redefining sustainable values using a case study from Indonesian cities
}

\author{
I. Hidayati \\ Department of Architecture and Planning, \\ Universitas Gadjah Mada, Indonesia
}

\begin{abstract}
Sustainability values are often associated with the three pillars of economic growth, social equity, and environmental conservation. However, the definition comes with the unspoken disclaimer, that the achievement of these sustainability values must be within a well-established system (social, political, and economic system). Yet, in developing countries, the social, political, and economic system is different to its counterpart, besides they are still struggling with economic growth and so less consideration has been given to other pillars. Consequently, the use of this world-wide definition of sustainability values has resulted in a lesssustainable level for most cities in developing countries. On the other hand, cities in these emerging countries have other values which are rarely considered as "sustainable". For example, informal street markets in developing cities, which are often accused as being the main cause for traffic congestion, are in fact similar to the shared-street concept emerging in cities in developed countries. This paper explores the "other" and "hidden" sustainability values from Indonesian cities thus serving as the basis for redefining sustainability values in developing countries. The exploration is based on de facto observation of Indonesia cities, and is described by employing a qualitative approach. The main result of this study indicates that "informality" can be considered as part of social equity which also contributes to economic growth and local wisdom as part of environmental conservation.
\end{abstract}

Keywords: sustainability values, informality, local wisdom, sustainability in developing countries. 


\section{Introduction}

The concept of sustainable development has been evolving since the term was used in the Brundtland Commission Report in 1987. It has been widely used in ecological and agricultural literature, which then also develops into a more holistic concept involving society, economic, and even ethical discourses [1]. In the urban planning field, the term of sustainable development refers to handling the impacts (more likely of environmental impacts) of a land use and structure plan [2]. However, considering the nature of urban planning, Næss [2] pointed out the different "type" of sustainable development achievement for developed and developing countries. For example, while developing countries struggle to fill basic infrastructure needs (e.g. clean water, proper sanitation, and housing) for its citizen in a "sustainable" way, developed countries are busy solving how to reduce noise pollution, which is least considered as problem by their counterpart.

Given the vast literature of sustainability ranging from its definition, values and criteria, which mostly originated from developed countries [3], the score of sustainability achievement in developing countries would obviously be low. A simple search using a search engine with the keywords "sustainability ranking countries" resulted in developed countries in the top rank [4, 5]. An exception comes from the Sustainable Society Index [6], where developing countries are in the top 10 for environmental wellbeing criteria, since their energy use and natural resource consumption are usually low. Still, other criteria such as human wellbeing and economic wellbeing place developed countries in the top rank.

Nevertheless, there exist success stories of sustainable initiatives and movements in developing countries, though mostly at the local community scale [7]. Hence, sustainable development and sustainability values are not exclusively bounded to developed countries. This paper aims to investigate and reveal how sustainability values are embedded in Indonesian cities through local customs and practices. Some of them are unique to developing countries, thus rarely discussed in scientific discourses which focused in the wealthy countries. As a basis for redefining sustainability values, a review of the sustainable development concept and sustainability values is presented, followed by an exploration of cases of Indonesian cities.

\section{A review of sustainable development concept and values}

The most common agreed concept of sustainable development is defined as development that is able to fill the need of the current generation without jeopardizing the need for future generations. Though the concept has been evolving, to translate the concept into a set of practical indicators is quite challenging. Not to mention that sustainability values are different, given the diverse social economic conditions.

Basiago [8] describes how the notion of "sustainable development" develops from the discussion of limit of growth versus long-term economic expansion and how it narrowed down in the urban planning field into the search for urban problems such as sprawling, congestion, and urban environmental degradation. 
Hence, Basiago [8] explored three elements of sustainability, which are economic sustainability, social sustainability, and environmental sustainability as elaborated previously by Kahn [9] and added the practical implementation of each element using case studies from Curitiba, Brazil; Kerala, India; and Nayarit, Mexico. Later on, Duxbury [10] added "culture" as the fourth element of sustainability, serving as a 'vehicle for sustainable values'. Nevertheless, the addition of "culture" separated from the "social" element is still in the debate, especially in how to apply the so-called "sustainable culture". Table 1 depicts practical definitions and commonly used keywords of each sustainable development's element [8-10].

Table 1: Definition and elements of sustainable development.

\begin{tabular}{|l|l|l|l|l|}
\hline & \multicolumn{1}{|c|}{$\begin{array}{c}\text { Economic } \\
\text { sustainability }\end{array}$} & $\begin{array}{c}\text { Social } \\
\text { sustainability }\end{array}$ & $\begin{array}{l}\text { Environmental } \\
\text { sustainability }\end{array}$ & $\begin{array}{c}\text { Cultural } \\
\text { sustainability }\end{array}$ \\
\hline $\begin{array}{l}\text { Practical } \\
\text { in urban } \\
\text { planning }\end{array}$ & $\begin{array}{l}\text { Provide basic } \\
\text { infrastructure } \\
\text { needs, } \\
\text { improve } \\
\text { quality of live } \\
\text { for urban } \\
\text { poor, enhance } \\
\text { urban } \\
\text { environment }\end{array}$ & $\begin{array}{l}\text { Alleviate } \\
\text { poverty, fair } \\
\text { distribution of } \\
\text { resources }\end{array}$ & $\begin{array}{l}\text { Reduce } \\
\text { ecological } \\
\text { footprint (e.g. } \\
\text { minimize } \\
\text { waste), } \\
\text { conform with } \\
\text { growth limit } \\
\text { heritage, } \\
\text { enrich human } \\
\text { culture that } \\
\text { contains } \\
\text { positive way } \\
\text { of life }\end{array}$ \\
\hline Keywords & $\begin{array}{l}\text { Growth } \\
\text { development } \\
\text { productivity } \\
\text { trickle down }\end{array}$ & $\begin{array}{l}\text { Equity } \\
\text { empowerment } \\
\text { accessibility } \\
\text { participation } \\
\text { sharing } \\
\text { institutional } \\
\text { stability }\end{array}$ & $\begin{array}{l}\text { Eco-system } \\
\text { integrity } \\
\text { carrying } \\
\text { capacity } \\
\text { biodiversity }\end{array}$ & $\begin{array}{l}\text { Inclusive } \\
\text { adaptive } \\
\text { process } \\
\text { integrated } \\
\text { community }\end{array}$ \\
& & & \\
\hline
\end{tabular}

Meanwhile, how to translate sustainability values into practice poses a different discourse. The main issue of this discussion circulates around (a) how to measure sustainability - e.g. at what level should we call one condition sustainable and what not; (b) the use of local versus global indicators for sustainability values [11]; and (c) the tendency to put environmental sustainability as the main objective of sustainable development $[8,12,13]$. Instead of establishing the sustainability indicators of each element (social, environmental, and economic), Alberti [11] elaborates how these three elements are intermingled in the urban dynamics and proposed three dimensions - urban patterns, urban flows, and urban quality - to be taken into account in measuring sustainability in terms of urban ecological space (see Table 2).

Though this approach in measuring sustainability in urban planning practices is able to describe the interrelationship between urban dynamics, the level of sustainability remains hard to define. A more advanced approach in measuring sustainability was presented by Zavrl and Zeren [14] using the case study of 
Table 2: $\quad$ Measuring urban sustainability.

\begin{tabular}{|c|c|c|}
\hline $\begin{array}{l}\text { Dimensions of } \\
\text { sustainability in } \\
\text { urban planning }\end{array}$ & Description & Example \\
\hline Urban patterns & $\begin{array}{l}\text { - Community (population, } \\
\text { economy, society) } \\
\text { - Structure (form, density, } \\
\text { differentiation, } \\
\text { connectivity) } \\
\text { - Functions (housing, } \\
\text { industry, services, } \\
\text { transportation) }\end{array}$ & $\begin{array}{l}\text { Transportation and land } \\
\text { use } \\
\text { - Density } \\
\text { - Land use } \\
\text { - Mobility } \\
\text { - Modal split }\end{array}$ \\
\hline Urban flows & $\begin{array}{l}\text { The flow of natural } \\
\text { resources (water, energy, } \\
\text { material) for cities to be } \\
\text { functioned (through } \\
\text { infrastructure and } \\
\text { technologies) }\end{array}$ & $\begin{array}{l}\text { Energy consumption } \\
\text { - Per capita } \\
\text { - Per sector } \\
\text { - By fuel } \\
\text { - By area }\end{array}$ \\
\hline Urban quality & $\begin{array}{l}\text { - Environmental quality } \\
\text { - Human health } \\
\text { - Efficiency } \\
\text { - Equity } \\
\text { - Diversity } \\
\text { - Accessibility } \\
\text { - Learning }\end{array}$ & 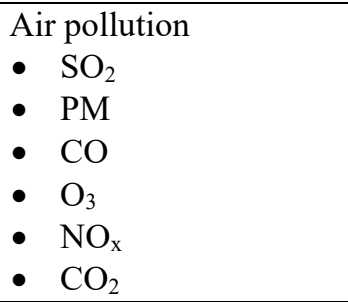 \\
\hline $\begin{array}{l}\text { Urban ecological } \\
\text { space }\end{array}$ & $\begin{array}{l}\text { Impacts of interactions } \\
\text { between urban patterns, } \\
\text { urban flows, and urban } \\
\text { quality }\end{array}$ & $\begin{array}{ll}\text { - } & \text { Greenhouse effect } \\
\text { - } & \text { Acidification } \\
\text { - } & \text { Winter smog } \\
\text { - } & \text { Photochemical } \\
& \text { smog }\end{array}$ \\
\hline
\end{tabular}

sustainable urban infrastructure from European Project COST C8 (Cooperation in Science and Technology). The sustainability assessment of COST C8 employed a matrix, in which each cell contains a question to conform the direction of sustainability given the current state. The direction of sustainability consists of a positive direction (marked as "definitely" and "yes"), neutral direction (marked as "as usual"), and negative direction (marked as "not enough" and "not at all"). These directions are used to answer the corresponding question, for example, "Are emissions to air, water, and soil within restrictions set locally and internationally?" For running the complete assessment, questions were developed for each element of sustainability; environmental, economic, and social. This approach proved to be useful in giving an insight into the state of sustainability within a limited time constraint. However, Zavrl and Zeren [14] noted that several obstacles such as lack 
of data and lack of commitment towards sustainability assessment could hinder the effectiveness of this approach.

The lack of commitment is mostly connected with how people perceive sustainability values; which are economic development, environmental protection, and social equity [15]. Surprisingly, information regarding how people perceive sustainability as a holistic concept was nowhere to be found, while only perception over the sub component of sustainability values exists [15]. Moreover, it was mentioned that there is a gap between perceived values and how these values are articulated in daily life [15]. This explains the reason why natural degradation still occurs while environmental awareness increases. This gap is considered to be wider in developing countries as Couret [16] describes the term of "sustainability for the rich", which refers to how people from developed countries could have more environmental awareness since their basic social and economic needs have been fulfilled.

\section{Sustainability in developing countries}

Given the differences in the state of social-economic-cultural between developed and developing countries, it is logical to state that in order to achieve sustainable development in developing countries should be started from the provision of basic infrastructure needs (i.e. clean water, basic healthcare, housing). However, the delivery of these basic needs has to be achieved at the least level of extraction of natural resources and focus on a long-term development goal [17], which is easier said than done. As noted by Saadatian et al. [18] people living in developing countries are already aware that their growing economic is unsustainable, and as a consequence, environmental problems emerge as the main challenge followed by social problems. Keivani [19] elaborated more about challenges that developing countries are facing to achieve sustainable development (see Table 3).

Thus, given more challenges to achieve the same level of sustainability, developing countries are required to redefine the concept of sustainable development by taking their particular condition into account, albeit international cooperation in terms of achieving sustainability also has to be restructured to give fair judgement for who is responsible for attaining sustainability [20]. In doing so, a different set of standards should be applied for developed and developing countries. In this regard, it is often suggested that developing countries who are just about to enter or are in the middle of industrial growth should not follow the previous path of developed countries, which were accused for over exploiting natural resources resulting in a big ecological footprint. Hence, developing countries should trace back their traditional community based ways of production instead [20], which is considered to be less energy consuming and thus more sustainable. This perspective of reviving traditional-community based production and redefining sustainability values is the basis of de facto observation and analysis in this paper. 
Table 3: Challenges to urban sustainability.

\begin{tabular}{|c|c|c|}
\hline $\begin{array}{c}\text { Elements of } \\
\text { sustainable } \\
\text { development }\end{array}$ & $\begin{array}{l}\text { Challenges in developed } \\
\text { countries }\end{array}$ & $\begin{array}{c}\text { Additional challenges in } \\
\text { developing countries }\end{array}$ \\
\hline Social & $\begin{array}{l}\text { Inclusivity } \\
\text { Equity } \\
\text { Fairness } \\
\text { Good governance } \\
\text { Safety } \\
\text { Accessibility }\end{array}$ & $\begin{array}{l}\text { Poverty } \\
\text { Exclusion } \\
\text { Practical case: slum }\end{array}$ \\
\hline Economic & Sustainable growth & $\begin{array}{l}\text { Lack of financial resources } \\
\text { Institutional problems (e.g. } \\
\text { lack of coordination, no } \\
\text { long-term vision) }\end{array}$ \\
\hline Environmental & $\begin{array}{l}\text { Climate change } \\
\text { Minimize energy use }\end{array}$ & $\begin{array}{l}\text { Rapid urbanization and } \\
\text { industrial growth versus } \\
\text { environmental protection }\end{array}$ \\
\hline $\begin{array}{l}\text { Access to utilities } \\
\text { and basic } \\
\text { infrastructure }\end{array}$ & - & $\begin{array}{l}\text { Lack of access to basic } \\
\text { infrastructure needs } \\
\text { Provision in informal } \\
\text { settlements }\end{array}$ \\
\hline $\begin{array}{l}\text { Urban form and } \\
\text { spatial } \\
\text { development }\end{array}$ & Compact city & $\begin{array}{l}\text { Relocation of informal } \\
\text { settlements } \\
\text { Peri-urban agglomeration } \\
\text { that often leads to gated } \\
\text { communities and social } \\
\text { exclusion }\end{array}$ \\
\hline $\begin{array}{l}\text { Multi-level } \\
\text { governance and } \\
\text { institutional } \\
\text { development }\end{array}$ & $\begin{array}{l}\text { Strategic planning in } \\
\text { line to achieve } \\
\text { sustainability }\end{array}$ & $\begin{array}{l}\text { Adoption of city } \\
\text { development strategies }\end{array}$ \\
\hline
\end{tabular}

\section{The bright side of informality}

Informality is often regarded as unsustainable as Couret [16] states that "the informal city is unsustainable", referring to its low density, gated community, and required extensive infrastructure network. However, informality in developing countries could also be seen as a way to survive, given the inability of formal institutions to provide adequate services to its inhabitants. Hence, in comparison with developed countries, the informal sector appears as a unique phenomenon, which requires particular treatment.

Another example of informality in developing countries is the informal market, commonly referred to as street markets, where stalls are erected in a particular street and are generally accused of creating traffic jams (see Figure 1). In an extreme case, Cervero [21] even mentioned that street vendors mostly occupy two- 
thirds of the road spaces. Indeed, a street market occupies part of the street, which contributes to higher side friction thus reducing the speed of traffic flow and creates congestion. However, less speed in the vicinity of a street market also means less risk of having a traffic accident. Moreover, the street market offers a vibrant public interaction by turning the particular street into a public space, which is in compliance with the concept of sustainable mobility and sustainable development accordingly [22]. This concept of incorporating public activities into street design is known as "shared space", in which it has to be noted that most of the shared space project aims to improve public space, not to improve traffic flow [23]. Thus, the concept of share space is unsuitable to be implemented in an arterial road that requires smooth traffic flow.

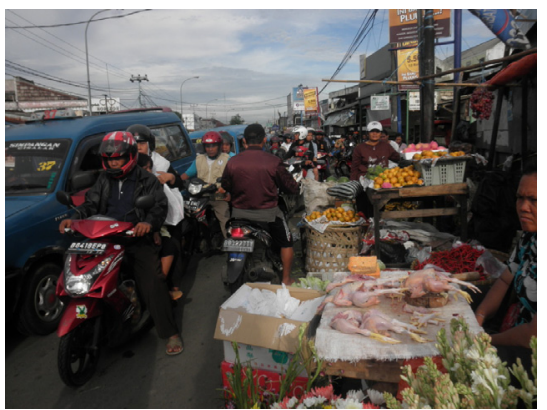

(a)

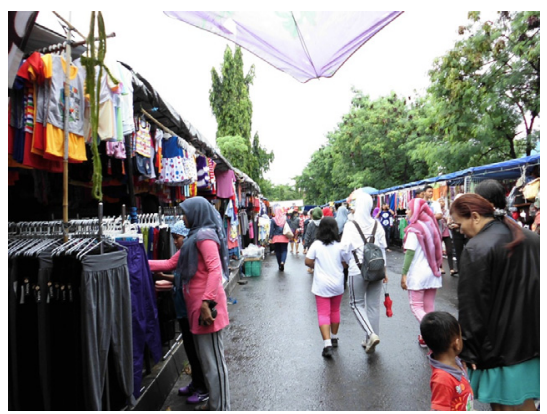

(b)

Figure 1: Typical informal street market in Indonesian cities. (Source: http://www.cirebonpos.com (a) and http://www.kartudiskonjogja.com (b).)

However, the problem which lies in developing countries, especially in Indonesian cities, is that road hierarchies just appear in the paper. In reality, land use which generates public activity (i.e. school, traditional market) is often found alongside arterial road thus creating congestion at specific hours. Responsible authorities try to solve this problem by enforcing traffic rules, which usually involves relocating the land use that caused the problem. The same method is applied when facing the same problem, even when the street market appears in a local road. In the latter case, there is no need to enforce traffic rules, since the street market is in the vicinity of a residential area and could even engage public interaction. There are even cases where a popular street market turns the street into a pedestrian area at a particular hour.

Here, the informal street market does not always constitute bad and has to be removed. With some preconditions (i.e. that it engages public interaction, is not on a major arterial road), an informal street market would encourage sustainable development through local economic activation, inducing a vibrant public interaction thus encouraging social equity, and improving road safety. 


\section{The wisdom from local movement}

The success story of programs and projects aiming at achieving sustainable development mostly comes from the local scale or involves local movement. In developing countries, local movement appears as collective action to solve urban problems especially in an informal sector, which faces the lack of basic infrastructure [24]. An example of a successful local movement is solid waste management in Sukunan community in Yogyakarta Province, Indonesia. In the early 2000s, various environmental problems arose due to enormous amounts of mismanaged domestic waste, such as flooding and even baby diapers were found in the paddy field. Since then, local movement has emerged as a response to improve domestic waste management by establishing a "waste bank", where domestic waste is separated and recycled by a local institution (plastic, paper, and other valuable waste such as steel and glass are sold to a third party while organic waste is recycled into compost and biogas). This movement is quite successful in improving the living quality in Sukunan through waste management and also provides additional income to the community. Hence, the Provincial Government has tried to replicate this movement in other local communities in Yogyakarta Province.

According to the sustainability principle, the work of local movement in improving their living quality reflects the values of sustainable development, which are inclusive, adaptive strategy, integrated community, culture conservation, and energy conservation. Local movement implies a higher degree of community participation to solve a specific urban issue. Since the scale of movement is not excessively big, the resources used are quite simple and low in energy consumption; in compliance with environmental conservations.

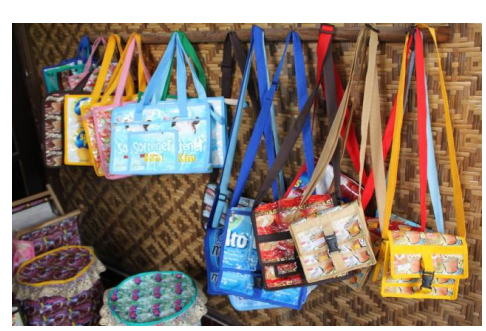

(a)

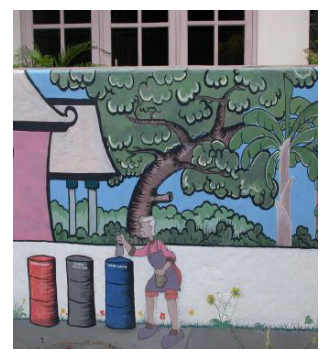

(b)

Figure 2: Handicraft made from domestic waste (a) and bins for waste segregation (b) [25].

Nonetheless, upscaling this local movement could be a bit tricky, since it will involve government support and coordination. In some cases, government involvement sometimes pushes the local movement backwards. Government is often regarded as having a lack of commitment and neglect the monitoring and evaluation stage. Hence, infrastructure provision could not be maintained optimally, coupled with a less sense of belonging from the local community [26]. 
Further research regarding government and local community cooperation should be conducted to provide more understanding in this matter.

\section{Conclusion}

Values of sustainable development are defined in the extension of environmental, social, and economic aspects. Thus, given the difference of social and economic conditions in developing countries and its developed counterparts, the values of sustainability should not be applied using the same standard. Based on de facto observation in Indonesian cities, it is proposed to add "informality" and "local movement" as part of sustainability values for developing cities. The "informality" can be considered as part of social equity which also contributes to economic growth and wisdom from local movement as part of environmental conservation.

\section{References}

[1] Barbara, B., Sustainability Assessment: A Review of Values, Concept, and Methodological Approaches, Issues in Agriculture 10. Consultative Group on International Agricultural Research: Washington, pp. 1-6, 1997

[2] Næss, P., Urban Planning and Sustainable Development, European Planning Studies, 9(4), pp. 503-524, 2001

[3] Koglin, T., Sustainable development in general and urban context: A literature review, Bulletin Lund University, 248, pp. 7-27, 2009

[4] Measuring Country Intangibles: Robecosam's Country Sustainability Ranking; Robecosam, Online. http:/www.robecosam.com/images/ Country-Sustainability-Paper-en.pdf

[5] Energy Trilemma Index; World Energy Council, Online. https://www.worldenergy.org/data/trilemma-index/

[6] Sustainable Society Index; Sustainable Society Foundation, Online. http://www.ssfindex.com/results-2014/world-totals/

[7] Green Economy Developing Countries Success Stories; United Nations Environment Programme (UNEP), Online. http://www.unep.org/pdf/ GreenEconomy_SuccessStories.pdf

[8] Basiago, A.D., Economic, social, and environmental sustainability in development theory and urban planning practice, The Environmentalist, 19, pp. 145-161, 1999

[9] Kahn, M., Concept, definitions, and key issues in sustainable development: the outlook for the future, Proceedings of the 1995 International Sustainable Development Research Conference, Manchester, England, March 27-28, 1995, pp. 2-13, 1995

[10] Duxbury, N., Cities, culture, and sustainable development, Summer Lab'12: Art, Climate Change, and Community Development, Torres Verdas, Portugal, September 5, 2012

[11] Alberti, M., Measuring urban sustainability, Environmental Impact Assessment Review, 16, pp. 381-424, 1996 
[12] Paul, B.D., A history of the concept of sustainable development: a literature review, The Annals of the University of Oradea, Economic Science Series, 17(2), pp. 576-580, 2008

[13] Jones, H., Sustainability reporting matters: what are national governments doing about it, The Association of Chartered Certified Accountants: London, p. 5, 2010

[14] Zavrl, M.S., and Zeren M.T., Sustainability of Urban Infrastructures, Sustainability, 2(9), pp. 2950-2964, 2010

[15] Leiserowitz, A.A., Kates, R.W., and Parris, T.M., Sustainability values, attitudes, and behaviors: a review of multinational and global trends, Annual Review of Environmental Resources, 31, pp. 413-444, 2006

[16] Couret, D.G., Sustainability in developing and developed countries, Archit. Polit, 42, pp. 1-5, 2008

[17] Kiamba, A., The sustainability of urban development in developing economies, Consilience: The Journal of Sustainable Development, 8(1), pp. 20-25, 2012

[18] Saadatian, O., Tahir, O.M., and Dola, K., Identifying challenges in implementing sustainable practices in a developing nation, Journal of Sustainable Development, 3(2), pp. 107-116, 2010

[19] Keivani, R., A review of the main challenges to urban sustainability, International Journal of Urban Sustainable Development, 1, pp. 5-16, 2010

[20] Haque, M.S., The fate of sustainable development under neo-liberal regimes in developing countries, International Political Science Review, 20(2), pp. 197-218, 1999

[21] Cervero, R., Linking urban transport and land use in developing countries, The Journal of Transport and Land Use, 6(1), pp. 7-24, 2013

[22] Hamilton Baillie, H., Shared space: reconciling people, places, and traffic, Built Environment, 34 (2), pp. 161-181, 2008

[23] Methorst, Rob., et.al., Shared space: safe or dangerous? A contribution to the objectification of a popular design philosophy, WALK21 Conference, October, 1-3, 2007, Toronto

[24] Pruijt, H., Urban movements, Blackwell Encyclopedia of Sociology, pp. 5515-5519, 2007

[25] Izzati, S.A., Belajar Proses Pengolahan Sampah berbasis Komunitas di Sukunan, Bachelor Thesis in Universitas Gadjah Mada, Indonesia, pp. V-8 and $\mathrm{V}-17,2012$

[26] Yuliatuti, N., and Saraswati, N., Environmental quality in urban settlement: The role of local community association in East Semarang sub-district, Procedia Social and Behavioral Sciences, 135, pp. 31-35, 2014 